\title{
OPTIMASI FREKUENSI KONTROL PADA SISTEM HYBRID WIND-DIESEL MENGGUNAKAN PID KONTROLER BERBASIS ACO DAN MFA
}

\author{
Muhammad Arrohman ${ }^{1}$, Risky Fajardika², Muhlasin ${ }^{3}$, Machrus Ali ${ }^{4}$ \\ 1,2,3,4 Teknik Elektro, Universitas Darul 'Ulum, Jombang \\ Email: ${ }^{1}$ muhammadarrohman09@gmail.com, ${ }^{2}$ rizky23dika@gmail.com, \\ 3muhlasin@ft-undar.ac.id, ${ }^{4}$ machrus@ft-undar.ac.id
}

\begin{abstract}
The power of the generating system is strongly influenced by frequency changes. The wind generating system is strongly influenced by the magnitude and speed of the gain as input power. The wind-diesel combined generating system is required to obtain optimum power quality. The hybrid swarm system is a controlled network of some renewable energy generation such as: wind turbine, solar cell, micro hydro and so on. Not optimal setting gain and small constant time on Load Frequency Control (LFC), causing its ability to be weak (weak line). In practice, wind-diesel systems are controlled with PID controller. Setting the gain value of the PID is conventional method, making it difficult to get the optimal value. In this research applied control design by using Intelligent Method to finding the optimum value of PID to adjust load frequency with Matlab program. This research uses Ant Colony Optimization (ACO) and Modification Firefly Algorithm (MFA). For comparison used without control method, conventional PID method and matlab auto tuning method. Wind-diesel modeling uses the transfer function of diagram of wind turbine and diesel. The results show that the smallest undershoot is PID-MFA Controller of $-1.529 .10^{-4}$ and the fastest settling time on the PID-ACO controller 11.5 seconds.

Keywords: ACO, frequency, MFA, PID, Wind-Diesel
\end{abstract}

\section{PENDAHULUAN}

Pada penelitian sebelumnya studi kestabilan operasi sistem hibrid membahas teknik pengaturan frekuensi dan teknik gabungan sistem fuel cell dan elektrolisa hybrid untuk meningkatkan kemampuan sistem mikrogrid dalam peningkatan kualitas daya dari permasalahan fluktuasi frekuensi. Sistem pemantauan (monitoring) dan pengaturan yang dilakukan bertujuan untuk menjaga kualitas daya dan menjaga kestabilan fluktuasi frekuensi. Hal ini disebabkan adanya daya random pada pembangkitan serta pada sisi beban. Selain itu sistem bertujuan untuk menjaga kestabilan fluktuasi aliran daya pada tieline aliran daya yang diakibatkan fluktuasi frekuensi dari interkoneksi sistem hybrid. Beberapa penelitian sebelumnya telah membahas pengaturan frekuensi pada Wind-Diese[1,2,3] untuk permasalahan pengaturan frekuensi.

\section{TINJAUAN PUSTAKA}

\section{Hibrid Deisel-Turbin Angin}

Sistem daya hybrid diesel-turbin angin dapat diterapkan pada daerah terpencil yang tingkat kecepatan angin cukup signifikan. Sistem ini memiliki karakteristik untuk menggerakkan generator dalam memproduksi listrik akan tetapi untuk penyediaan energi pada sistem jaringan terkoneksi tidak ekonomis[1]. Hasil pembangkitan energi listrik dari sistem hybrid Wind-Diesel dapat menyediakan pelayanan yang baik bagi pelayanan beban ke konsumen. Namun, semua itu tergantung pada tipe dan karakteristik kontrol pembangkitan. Variasi sistem frekuensi harus dapat dijaga kestabilannya agar peralatan dapat beroperasi dengan baik dan efisien. Strategi yang berbeda dapat diterapkan dengan mereduksi perbedaan pembangkitan dan beban serta mengatur deviasi frekuensi sistem. Adapun strategi-strategi yang dapat dilakukan dengan cara pengaturan kontrol beban tiruan, prioritas switching kontrol 
beban, penggunaan flywheel, superkonduktor magnetik dan baterai. Model dalam studi kasus ini terdiri dari sub sistem: model dinamik turbin angin, model dinamik diesel, kontrol kecepatan sudu turbin angin dan model dinamik generator $[5,6,7]$. Blok diagram fungsi transfer Turbin Angin-Diesel pada Gambar 1 sebagai berikut.

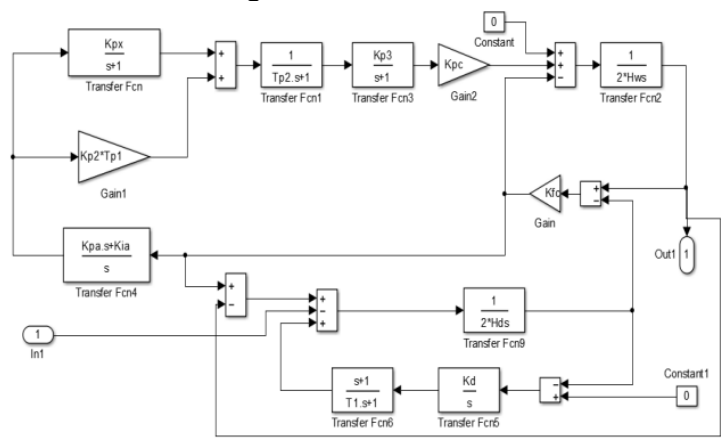

Gambar 1. Pemodelan Turbin Angin- Diesel

Parameter pembangkit listrik hybrid wind diesel dapat dilihat pada Tabel 1.

Tabel 1. Parameter Wind-Diesel

\begin{tabular}{|c|l|c|}
\hline$\Delta \omega_{1}$ & Frekuensi generator Angin (hz) & - \\
\hline$\Delta \mathrm{P}_{\text {load }}$ & Perubahan Beban Masuk (p.u.kW) & - \\
\hline$\Delta \mathrm{P}_{\text {wtg }}$ & Pembangkit Tenaga Angin (p.u.kW) & - \\
\hline $\mathrm{H}_{\mathrm{w}}$ & Konstanta dari Sistem Angin (s) & 3,5 \\
\hline $\mathrm{H}_{\mathrm{d}}$ & Konstanta dari Sistem Angin (s) & 8,5 \\
\hline $\mathrm{s}$ & Laplace Komplek Frekuensi Generator & - \\
\hline$\Delta \mathrm{P}_{\text {max }}$ & Pengaturan Daya Maksimum & 0 \\
\hline$\Delta \mathrm{P}_{\mathrm{t}}$ & Pembangkit Tenaga Diesel (p.u.kW) & - \\
\hline $\mathrm{P}_{\mathrm{r}}$ & Kapasitas Area (kW) & 350 \\
\hline$\Delta \omega_{2}$ & Frekuensi generator Diesel (hz) & - \\
\hline $\mathrm{K}_{\mathrm{pc}}$ & Karakteristik Gain Blade & 0,08 \\
\hline $\mathrm{K}_{\mathrm{FC}}$ & Gain Fluida Kopling & 16,2 \\
\hline $\mathrm{K}_{\mathrm{P} 3}$ & Gain Data Respon Lapangan & 1,4 \\
\hline $\mathrm{K}_{\mathrm{P} 2}$ & Gain Aktuator Hidrolik & 1,25 \\
\hline $\mathrm{K}_{\mathrm{P} 1}$ & Gain Kontrol Program & 4 \\
\hline $\mathrm{Tp}_{1}$ & Waktu Konstan dari Aktuator Hidrolik & 0,$6 ;$ \\
$\mathrm{Tp}_{2}$ & & 0,041 \\
\hline
\end{tabular}

\section{METODE PENELITIAN}

\section{A. PID Controller}

Kontrol PID adalah sistem kontrol gabungan antara kontrol proporsional, integral, dan turunan (derivative). Pada metode ini, penalaan dilakukan dalam kalang tertutup dimana masukan referensi yang digunakan adalah fungsi tangga (step). Pengendali pada metode ini hanya pengendali proporsional. Kp, dinaikkan dari nilai 0 hingga nilai kritis $\mathrm{Kp}$, sehingga diperoleh keluaran yang terus-menerus berosilasi dengan amplitudo yang sama. Nilai kritis $\mathrm{Kp}$ ini disebut sebagai ultimated gain. Nilai ultimated period, Tu, diperoleh setelah keluaran sistem mencapai kondisi yang terus menerus berosilasi.

\section{B. Modification Firefly Algorithm (MFA)}

Algorithm Firefly (FA) pertama ditemukan oleh Dr. Xin-She Yang, di Universitas Cambridge pada tahun 2007. MFA adalah modifikasi FA dengan melihat karakter obyek yang diteliti dalam hal ini menghilangkan variabel alpha. Pada proses permasalahan optimisasi, kecerahan cahaya kunang-kunang adalah sebanding dengan nilai dari fungsi tujuan. Bentuk lain dari kecerahan dapat didefinisikan pada cara yang sama untuk fungsi fitness pada algoritma genetika[8,9]. Berdasarkan pada ketiga peraturan ini, langkah dasar dari algoritma kunang-kunang dapat diringkas sebagai pseudo code.

Data parameter-parameter standar MFA yang digunakan ditunjukkan pada Tabel 2 berikut:

Tabel 2. Parameter MFA

\begin{tabular}{|c|c|}
\hline Parameter & Nilai \\
\hline Beta & 0.2 \\
\hline Gamma & 1 \\
\hline Dimensi & 3 \\
\hline Jumlah Kunang-Kunang & 50 \\
\hline Iterasi maksimum & 50 \\
\hline
\end{tabular}

\section{Ant Colony Optimization (ACO)}

Algoritma ACO diperkenalkan oleh Lumer dan Faieta (1994). Algoritma ini merupakan algoritma yang meniru perilaku semut mayat yang menyortir larva semut. Algoritma ACO menyediakan partisi yang relevan dari data tanpa pengetahuan pusat klaster awal. Terdapat semut agen yang melakukan perpindahan secara acak pada grid dua dimensi dimana dalam grid tersebut terdapat objek yg tersebar secara acak, dan ukuran grid tergantung pada jumlah objek. Ant colony yang dipilih atau diizinkan untuk bergerak dalam grid, akan mengambil objek dan juga menjatuhkan objek yang dipengaruhi 
oleh kesamaan dan kepadatan objek[10,11,12]. Data parameter-parameter standar ACO yang digunakan ditunjukkan pada Tabel 3 berikut:

Tabel 3. Parameter ACO

\begin{tabular}{|c|c|}
\hline Parameter & Nilai \\
\hline Node & 100 \\
\hline Max_It & 50 \\
\hline Alpha & 1 \\
\hline Beta & 2 \\
\hline rho & 0.1 \\
\hline c & 100 \\
\hline
\end{tabular}

HASIL DAN PEMBAHASAN

Respon Frekuensi Wind-Diesel

Dengan memasukkan parameterparameter dan running program pada plant pembangkit hybrid wind-diesel didapatkan nilai konstanta PID pada masing-masing model. Konstanta Kp, Ki dan Kd pada PID dapat dilihat pada table 4 dibawah ini:

Tabel 4. Konstanta PID Wind Diesel

\begin{tabular}{|l|l|l|r|r|r|}
\hline & Unc & PID & ACO & \multicolumn{1}{|c|}{ FA } & \multicolumn{1}{c|}{ MFA } \\
\hline $\mathrm{Kp}$ & - & 1 & 24.9428 & 16.4211 & 28.5215 \\
\hline $\mathrm{Ki}$ & - & 1 & 11.4951 & 2.7927 & 9.8171 \\
\hline $\mathrm{Kd}$ & - & 0 & 0.8453 & 0.0692 & 0.0011 \\
\hline
\end{tabular}

Gambar blok rangcangan simulasi WindDiesel dapat dilihat pada Gambar 2:

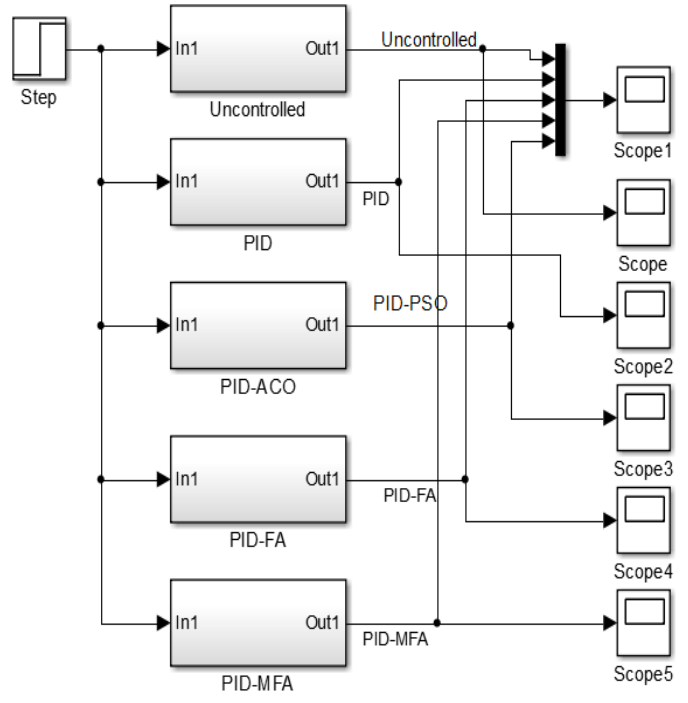

Gambar 2. Pemodelan blok Wind-Diesel
Desain model dapat dilihat pada Gambar 3, dan 4.

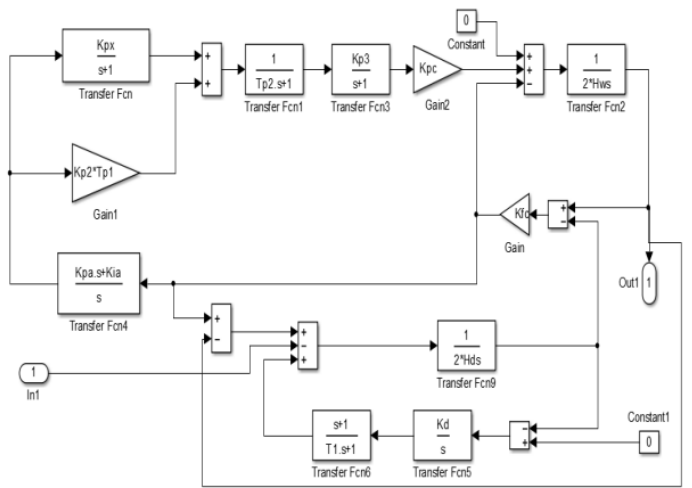

Gambar 3. Pemodelan Uncontrolled

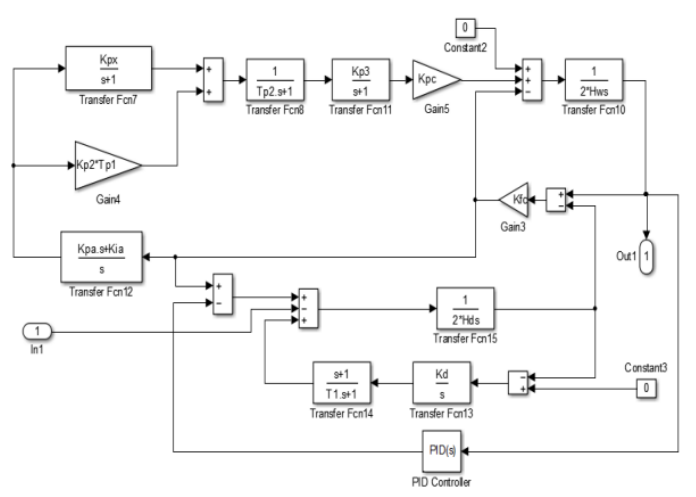

Gambar 4. Pemodelan PID/PID-ACO/PIDFA/PID-MFA

Hasil penelitian dapat digambarkan pada Gambar 5.

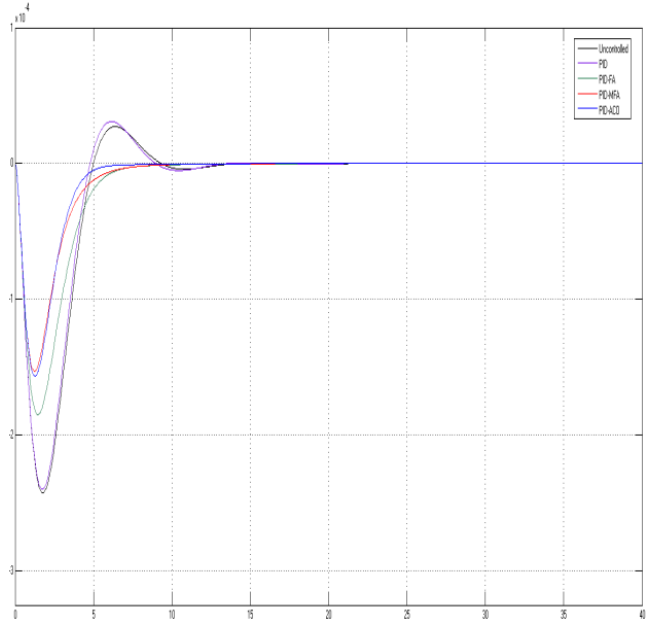

Gambar 5. Hasil Respon Wind Diesel berbagai Kontroler 
Dari hasil grafik diatas dapat dijelaskan sebagai berikut : Tanpa controller didapatkan nilai undershoot pada $\mathrm{t}=1,6$ sebesar $2,238.10^{-4}$ dan overshoot pada $t=6,14$ sebesar $3,092.10^{-5}$ dengan settling time 23,4 detik. PID controller didapatkan nilai undershoot pada $\mathrm{t}=1,6$ sebesar $-2,238.10^{-4}$ dan overshoot pada $t=6,14$ sebesar $3,092.10^{-5}$ dengan settling time 23,4 detik. PID-ACO didapatkan nilai undershoot pada $t$ $=1,48$ sebesar $-1,592 \cdot 10^{-4}$ dengan overshoot $2,242 \cdot 10^{-5}$ pada $t=6,9$ dengan settling time 11,5 detik. PID-FA didapatkan nilai undershoot saat $\mathrm{t}=1,45$ sebesar $-1,8481.10^{-4}$ tanpa overshoot dengan settling time 22,4 detik. PID-MFA didapatkan nilai undershoot pada $\mathrm{t}=1,26$ sebesar $-1,529.10^{-4}$ tanpa overshoot dengan settling time 18,1 detik.

\section{KESIMPULAN}

Hasil penelitian menunjukkan bahwa fungsi kecerdasan buatan sangat bermanfaat untuk menentukan konstanta PID controller. Dari hasil penelitian yang telah dilakukan menunjukkan bahwa undershoot terkecil sebesar -1,529.10-4 adalah PID-MFA controller dan settling time tercepat pada PIDACO controller 11,5 detik. Penelitian ini nantinya bisa diteruskan dengan menggunakan metode kecerdasan buatan lainnya.

\section{DAFTAR PUSTAKA:}

[1] Robandi,I, Modern Power System Control, ANDI, Yogyakarta, 2006.

[2] Robandi,I. Desain Sistem Tenaga Modern: Optimasi, Logika Fuzzy, dan Algoritma Genetika, ANDI, 2006.

[3] Abidin,Z, Pengaturan Frekuensi Beban Hibrid Turbin Angin Diesel Dengan Menggunakan Algoritma Genetika, Jurnal Teknika, 2010.

[4] T.S. Bhatti, Load frequency control of isolated wind diesel hybrid power systems Sciencedirect: Energy Conversion and Management,1995.
[5] Mohit Singh, Dynamic Models for Wind Turbines and Wind Power Plant, 2011.

[6] Tan Wen, Load frequency control for winddiesel hybrid systems, Control Conference (CCC), 2011 30th Chinese.

[7] Hou,J. Load frequency control of wind diesel hybrid power systems via predictive control. Control Conference (CCC), 2012 31st Chinese.

[8] Machrus Ali, Akemad Suhadak, Optimisasi Steering Control Mobil Listrik Auto-Pilot Menggunakan Metode Firefly Algorithm (FA), Semnasinotek-2017, UN PGRI, Kediri, pp:61-68.

[9] Rukslin, Muhamad Haddin, Agus Suprajitno, Pitch Angle Controller Design on the Wind Turbine with Permanent Magnet Synchronous Generator (PMSG) Base on Firefly Algorithms (FA), ISEMANTIC-2016, IEEE International Conference, Udinus, Semarang, pp: 1317.

[9] Dwi Ajiatmo, Agus Raikhani, Desain Optimasi LFC Pada Micro-Hydro Menggunakan Metode Ant Colony Optimization (ACO), Semnasinotek-2017, UN PGRI, Kediri, pp: 75-81

[10] Mochammad Nur Masrukhan, Mochamad Piono Mulyo, Dwi Ajiatmo, Machrus Ali, Optimasi Kecepatan Motor DC Menggunakan PID Dengan Tunning Ant Colony Optimization (ACO) Controller, SENTIA-2016, Polinema, Malang, pp: B49-B52

[11] Rukslin, Muhlasin, Penggunaan Methode Ant Colony Algorithm untuk Pengaturan Pitch Angle pada Turbin Angin, Semnasinotek-2017, UN PGRI, Kediri, pp: 35-42

[12] Dorigo M, Stutzle T, Ant Colony Optimization. Cambridge (MA), MIT Press; 2004.

[14] Yang, X.-S, Firefly algorithm, Levy flights and global optimization, Research and Development in Intelligent Systems XXVI, 26, 2010, pp: 209-218. 